\title{
Analysis of the interaction of monoclonal antibodies with surface IgM on neoplastic B-cells
}

\author{
MS Cragg', L Zhang'2, RR French ${ }^{1}$ and MJ Glennie ${ }^{1}$ \\ ${ }^{1}$ Tenovus Research Laboratory, Southampton General Hospital, Tremona Road, Southampton, SO16 6YD, UK; ${ }^{2}$ Medical Research Laboratory of Molecular \\ Biology, Hills Road, Cambridge, CB2 2QH, UK
}

Summary In vitro studies identified three Burkitts lymphoma cell lines, Ramos, MUTU-I and Daudi, that were growth inhibited by anti-IgM antibody. However, only Ramos and MUTU-I were sensitive to monoclonal antibodies (mAb) recognizing the Fc region of surface IgM (anti$\mathrm{F} c \mu$ ). Experiments using anti-Fc $\mathrm{mAb}$ (single or non-crossblocking pairs), polyclonal anti- $\mu \mathrm{Ab}$, and hyper-crosslinking with a secondary layer of $\mathrm{Ab}$, showed that growth inhibition of B-cell lines was highly dependent on the extent of IgM crosslinking. This was confirmed by using $\mathrm{Fab}^{\prime}, \mathrm{F}\left(\mathrm{ab} \mathrm{b}^{\prime}\right)_{2}$ and $\mathrm{F}\left(\mathrm{ab} \mathrm{b}^{\prime}\right)_{3}$ derivatives from anti-Fc $\mathrm{mAb}$, where increasing valency caused corresponding increases in growth arrest and apoptosis, presumably as a result of more efficient BCR-crosslinking on the cell surface. The ability of a single mAb to induce growth arrest was highly dependent on epitope specificity, with mAb specific for the Fc region ( $\mathrm{C} \mu 2-\mathrm{C} \mu 4$ domains) being much more effective than those recognizing the Fab region (anti-L chain, anti-Id and anti-Fd $\mu$, or $\mathrm{C} \mu 1$ ). Only when hyper-crosslinked with polyclonal anti-mouse IgG did the latter result in appreciable growth inhibition. Binding studies showed that these differences in function were not related to differences in the affinity, but probably related to intrinsic crosslinking capacity of $\mathrm{mAb}$.

Keyword: monoclonal antibody; transmembrane signalling; surface IgM; crosslinking; antibody immunotherapy

In vitro studies have shown that crosslinking of the B-cell receptor (BCR) by anti-IgM monoclonal antibody $(\mathrm{mAb})$ can have either stimulatory or inhibitory effects depending on the maturation state of the cell (De Franco et al, 1982; Hasbold and Klaus, 1990.). Of particular interest in the field of immunotherapy is that crosslinking of the BCR on B lymphoma cells can induce inhibitory signals that may result in cell cycle arrest and apoptosis (Hasbold and Klaus, 1990; Marches et al, 1995). There is growing evidence that such transmembrane signalling is critical to much of the therapeutic success of anti-idiotype (Id) mAb in the treatment of non-Hodgkins lymphoma (NHL). For example the study by Vuist et al (1994) highlighted the close correlation between the therapeutic success of anti-Id $\mathrm{mAb}$ in NHL and the ability of the treatment $\mathrm{mAb}$ to stimulate protein tyrosine phosphorylation in frozen archive tumour material. Since tyrosine phosphorylation following crosslinking of surface immunoglobulin ( $\mathrm{Ig}$ ) is one of the first steps in the cascade of intracellular signalling events (Gold et al, 1991; Sefton and Campbell, 1991), this positive correlation suggests that the key to the success of anti-Id mAb may stem from their ability to crosslink surface Ig and deliver a direct anti-proliferative signal to the tumour. The importance of crosslinking was further suggested by the observation that although cells from non-responding patients could not be induced to signal with anti-Id mAb, they were responsive to stimulation with a polyclonal anti- $\mu \mathrm{Ab}$, which, because it recognizes multiple epitopes on the $\mathrm{BCR}$, possesses a far greater potential for crosslinking than a single $\mathrm{mAb}$.

While these results indicate the importance of crosslinking in the inhibitory action of anti-Id $\mathrm{mAb}$, the extent of crosslinking neces-

Received 8 June 1998

Revised 5 August 1998

Accepted 7 August 1998

Correspondence to: MS Cragg sary for achieving inhibition, and the antibody binding requirements, have not been fully defined. In this paper, we describe the sensitivity of a panel of Burkitt's lymphoma cell lines to the growth inhibitory effects of anti-IgM mAb, and a series of experiments designed to look at the effects of IgM domain specificity, BCR crosslinking, and hyper-crosslinking on growth inhibition.

\section{MATERIALS AND METHODS}

\section{Cell lines and antibodies}

The Burkitt's lymphoma cell lines Daudi, Ramos, Ramos-sublines RA.1 and EHRB, Raji, Namalwa, MUTU-I and MUTU-61E (kindly given by Dr A Milner and Prof. Chris Gregory, Birmingham, UK), Nalm-6 (kindly given by Dr Bill Cushley, Glasgow, UK) and Bristol-8 cells were used in this study. All cell lines were maintained in supplemented RPMI-1640 [RPMI-1640 medium containing glutamine $(2 \mathrm{mM})$, pyruvate $(1 \mathrm{mM})$, penicillin and streptomycin $\left(100 \mathrm{IU} \mathrm{ml}^{-1}\right)$, fungizone $\left(2 \mu \mathrm{g} \mathrm{ml}^{-1}\right)$ and $10 \%$ fetal calf serum (FCS) (Myoclone) (Gibco Ltd, Paisley, UK)]. Monoclonal antibodies used in these studies included: anti- $\mu$, M15/8, ZL7/5 and Mc41/24G10 (all anti-Fc $\mu$ ), and anti- $\lambda$, M15/2 and Mc24/1C6, all raised in this laboratory (Bonardi et al, 1993; Zhang et al, 1995), the anti-Fab $\mu$ antibodies M-2E6 (ATCC, Rockville, MA, USA) and XG9 (kindly given by Dr Patricia Mongini, New York, NY, USA) (Rudich et al, 1988). In addition, we used three anti-Id mAb, ZL16/1, ZL16/3 and ZL16/11, specific for the surface IgM of the Ramos cell line and one anti-Id mAb, ZL15/27, specific for the surface IgM of the Daudi cell line (Zhang et al, 1995). Polyclonal sheep anti-mouse IgG was raised at Tenovus.

All hybridoma lines secreting mAb were expanded in tissue culture and purified from culture supernatant using a Protein A column (Glennie et al, 1993). F(ab') fragments of IgG were 
prepared by limited proteolysis with pepsin at $\mathrm{pH} 4.0-4.2$ (Glennie et al, 1993). Fab' from M15/8 and Mc24/1C6 F(ab'), was produced by reduction with $20 \mathrm{~mm}$ 2-mercaptoethanol for $30 \mathrm{~min}$ at $25^{\circ} \mathrm{C}$, followed by alkylation with excess iodoacetamide.

\section{Measurement of $\left[{ }^{3} \mathrm{H}\right]$ thymidine incorporation}

Cells $\left(5 \times 10^{4}\right)$ were aliquoted into each well of a 96-well microtitre plate (Gibco) and incubated in $200 \mu$ l of supplemented RPMI medium containing the required concentration of $\mathrm{mAb}$ for $24 \mathrm{~h}$ at $37^{\circ} \mathrm{C}$ before pulsing overnight with $0.5 \mu \mathrm{Ci}\left[{ }^{3} \mathrm{H}\right]$ thymidine (Amersham International PLC, UK) in $50 \mu \mathrm{l}$ RPMI as described previously (Tutt et al, 1991). The incorporation of $\left[{ }^{3} \mathrm{H}\right]$ thymidine into DNA was assessed by harvesting the cells onto glass microfibre filters and washing with water. Experimental points were determined in triplicate. The variation between triplicates was less than $10 \%$.

\section{Preparation of anti-Fc $\mu$ (M15/8) multimers}

$\mathrm{M} 15 / 8 \mathrm{~F}\left(\mathrm{ab}^{\prime}\right)_{3}$ was prepared using the bis-maleimide crosslinker, $o$-phenylenedimaleimide, as described by Tutt et al (1991) for the preparation of bispecific trimers.

\section{Hyper-crosslinking experiments}

$\mathrm{mAb}$ at a concentration of $10 \mu \mathrm{g} \mathrm{ml}^{-1}$ were first allowed to bind to cells at a concentration of $2.5 \times 10^{5} \mathrm{ml}^{-1}$ for $15 \mathrm{~min}$ at $4^{\circ} \mathrm{C}$. Cells were then separated from excess unbound antibody in the supernatant by centrifugation, and the supernatant removed. Cells were resuspended at a concentration of $2.5 \times 10^{5} \mathrm{ml}^{-1}$ in medium containing polyclonal sheep anti-mouse IgG at $20 \mu \mathrm{g} \mathrm{ml}^{-1}$, to act as a hyper-crosslinking reagent, plated out as $200 \mu \mathrm{l}$ aliquots on 96-well microtitre plates, and incubated for $24 \mathrm{~h}$ at $37^{\circ} \mathrm{C}$ before pulsing overnight with $0.5 \mu \mathrm{Ci}\left[{ }^{3} \mathrm{H}\right]$ thymidine. Cells were then harvested and incorporated radioactivity determined as described above.

\section{Measurement of apoptosis using propidium iodide}

Samples were assessed by the method of Nicoletti et al (1991). Briefly, aliquots of cells $\left(10^{6}\right)$ were centrifuged for $5 \mathrm{~min}$ at $500 \mathrm{~g}$ and then washed once in phosphate-buffered saline (PBS). The cells were then resuspended in hypotonic fluorochrome solution $\left(50 \mu \mathrm{g} \mathrm{ml}^{-1}\right.$ propidium iodide (PI), $0.1 \%(\mathrm{w} / \mathrm{v})$ sodium citrate, $0.1 \%(\mathrm{w} / \mathrm{v})$ Triton $\mathrm{X}-100)$ and incubated in the dark at $4{ }^{\circ} \mathrm{C}$ overnight or $1 \mathrm{~h}$ at room temperature. PI staining of DNA from 10 000 cells was detected on a FACScan flow cytometer (Becton Dickinson) and the proportion of DNA giving fluorescence below the $\mathrm{G} 1 / 0$ peak was taken as a measure of apoptosis.

\section{Agarose gel DNA fragmentation analysis}

Following incubation of cells under appropriate conditions, samples containing $1-2 \times 10^{6}$ cells were harvested. Twenty microlitres TE-SLS (10 mm EDTA, $50 \mathrm{~mm}$ Tris-HCl pH 8.0, 0.5\% (v/v) sodium lauryl sarkosinate (SLS, Sigma)) plus $0.5 \mathrm{mg} \mathrm{ml}^{-1}$ proteinase K (Sigma) was then added, and the samples incubated for $1-2 \mathrm{~h}$ at $50^{\circ} \mathrm{C} .10 \mu 10.16 \mathrm{mg} \mathrm{ml}^{-1}$ RNase A (Sigma) was added and samples were incubated for a further $1-2 \mathrm{~h}$ at $50^{\circ} \mathrm{C}$. The temperature of the samples was then increased to $70^{\circ} \mathrm{C}$ for addition of $10 \mu \mathrm{l}$ of loading buffer [10 mM EDTA, 1\% (w/v) low melting point agarose, $0.25 \%(\mathrm{w} / \mathrm{v})$ bromophenol blue, $40 \%(\mathrm{w} / \mathrm{v})$ sucrose]. Samples were loaded into dry wells of $1 \%(\mathrm{w} / \mathrm{v})$ agarose gels containing $0.5 \mathrm{mg} \mathrm{ml}^{-1}$ ethidium bromide and run either overnight at $30-40 \mathrm{~V}$ or for $2-3 \mathrm{~h}$ at $80 \mathrm{~V}$, in TAE ( $89 \mathrm{~mm}$ Tris, $89 \mathrm{~mm}$ boric acid, 2 mм EDTA, pH8.4). DNA was visualized by UV light.

\section{Radioiodination of antibodies}

$\mathrm{mAb}$ were trace radiolabelled for binding studies using carrier-free ${ }^{125}$ I (Amersham International plc) and IODO-BEADS (Pierce Chemicals Co., Rockford, IL, USA) as the oxidizing reagent. Radioactivity was measured in a Rackgamma spectrometer (LKB). The immunoreactive component of each mAb [ $\left.{ }^{125} \mathrm{I}\right] \mathrm{IgG}$ preparation was estimated by determining what fraction bound to a large antigen excess as described by Elliot et al (1987). Typically, $\mathrm{mAb}$ were found to contain $50-85 \%$ reactive material.

\section{Binding of [ $\left.{ }^{125}\right] \mathrm{mAb}$ to the cell surface}

The binding of radiolabelled mAb to cells was determined as described by Elliot et al (1987). Radiolabelled mAb were serially diluted before incubating with cells $\left(0.5-1.25 \times 10^{6} \mathrm{ml}^{-1}\right.$, final volume $1 \mathrm{ml}$ ) in RPMI medium containing 10\% FCS for $2 \mathrm{~h}$ at $37^{\circ} \mathrm{C}$. Endocytosis of cell bound $\mathrm{mAb}$ was prevented by inclusion of sodium azide (15 mM) and 2-deoxyglucose (50 mM). The cells were separated from the aqueous phase by centrifugation through a 1.1:1 (vol/vol) mixture of dibutyl phthalate:dioctyl phthalate. Radioactivity was measured in a Rackgamma spectrometer (LKB).

\section{RESULTS}

\section{Sensitivity of Burkitt's lymphoma cell lines to anti-BCR induced growth inhibition}

In preliminary experiments, eight Burkitt's lymphoma cell lines, Daudi, Bristol-8, MUTU-I, MUTU-61E, Nalm-6, Namalwa, Ramos and Raji, were assessed for their sensitivity to anti-Fc $\mu$ $\mathrm{mAb}$ in growth assays. The results obtained with the Ramos, MUTU-I, and Daudi lines with the anti-Fc $\mu$ mAb M15/8 are shown in Figure 1. Of the eight lines tested, only Ramos and MUTU-I were sensitive to $\mathrm{M} 15 / 8$, showing a $60-80 \%$ inhibition of $\left[{ }^{3} \mathrm{H}\right]$ thymidine incorporation at a mAb concentration of $10 \mu \mathrm{g} \mathrm{ml}^{-1}$ (Figure 1A, B). Two other anti-Fc $\mu$ mAb, Mc41/24G10 and ZL7/5, had similar inhibitory activity on these particular cell lines.

The sensitivity of the eight cell lines to polyclonal anti- $\mu$ Ab was also determined. Ramos and Mutu- 1 were both highly sensitive to polyclonal anti- $\mu$, giving up to $90 \%$ inhibition of $\left[{ }^{3} \mathrm{H}\right]$ thymidine incorporation at $10 \mu \mathrm{g} \mathrm{ml}^{-1}$ (Figure 1A, B). In addition, the Daudi cell line was sensitive (Figure 1C) which, in the light of its insensitivity to anti-Fc $\mu \mathrm{mAb}$, was of particular interest and suggested that the extent of crosslinking of the BCR was probably important in determining growth arrest. The other five cell lines were insensitive to polyclonal anti- $\mu$ antibody. Four of the cell lines, Nalm-6, Bristol-8, Raji and Namalwa, expressed relatively low to medium levels of surface IgM compared with Ramos, Daudi, MUTU-I and MUTU-61E (results not shown). Since each of the former group were insensitive to growth arrest, this suggested that although a high level of surface IgM did not guarantee anti- $\mu \mathrm{mAb}$-induced inhibition, it was a prerequisite for sensitivity. 
A

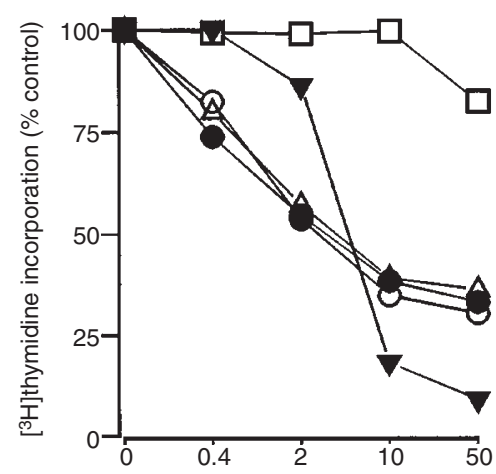

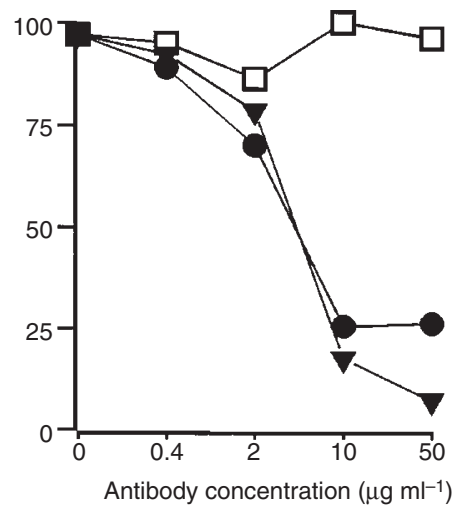

C

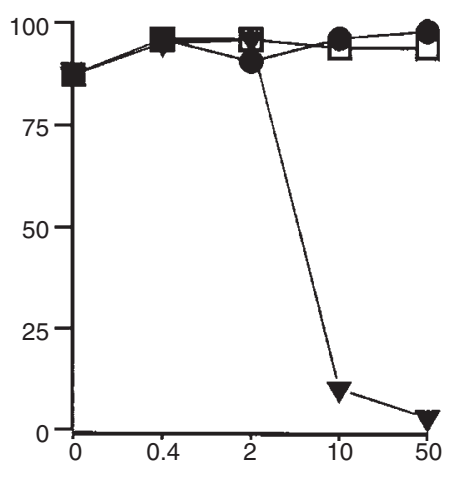

Figure 1 Growth inhibition of Ramos, MUTU-I, and Daudi cell lines following treatment with monoclonal or polyclonal anti- $\mu$ antibody. Ramos (A), MUTU-I (B), and Daudi $(\mathbf{C})$ cells were incubated with antibody at the concentration shown for $24 \mathrm{~h}$, and then with $0.5 \mu \mathrm{Ci}\left[{ }^{3} \mathrm{H}\right]$ thymidine for $16 \mathrm{~h}$. Cells were then harvested and counted to determine incorporation of radioactivity. The results represent the mean of triplicate determinations. $\square$, irrelevant mAb; $\boldsymbol{\nabla}$, sheep anti-mouse

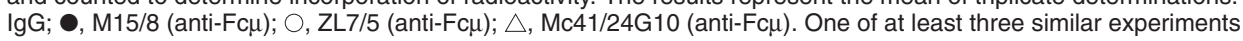

Table 1 The induction of apoptosis in EHRB cells by anti-Fcu mAb

\begin{tabular}{|c|c|c|}
\hline Experiment & Treatment & $\%$ Apoptotic ${ }^{d}$ \\
\hline & None & $7 \pm 1$ \\
\hline & Anti-Fc $\mu^{a}$ & $31 \pm 5$ \\
\hline \multirow[t]{3}{*}{ Anti-Fc $\mu$ multimers } & Anti-Fc $\mu$ Fab'b & $11.5 \pm 7$ \\
\hline & Anti-Fc $\mathrm{F}\left(\mathrm{ab} \mathrm{b}^{\prime}\right)_{2}^{\mathrm{b}}$ & $35 \pm 13$ \\
\hline & Anti-Fc $\mu F\left(a b^{\prime}\right)_{3}^{b}$ & $47 \pm 5$ \\
\hline \multirow[t]{2}{*}{ Hyper-crosslinking } & Anti-Fc $\mu^{c}$ & $12 \pm 6$ \\
\hline & Anti-Fc $\mu+$ sheep anti-mouse IgGc & $62 \pm 17$ \\
\hline
\end{tabular}

Cells were incubated with treatment antibody as described below and the level of apoptosis assessed by propridium iodide analysis. The anti-Fcu mAb used was M15/8. a,bCells were incubated with mAb at $1 \mu \mathrm{g} \mathrm{ml}^{-1}$ for $48 \mathrm{~h}$. ${ }^{c}$ Cells were incubated with $10 \mu \mathrm{g} \mathrm{ml}^{-1}$ anti-Fc $\mu$ mAb for $15 \mathrm{~min}$, then washed and sheep anti-mouse IgG added for $48 \mathrm{~h}$ as described in Figure 5. dValues represent mean \pm SD for three experiments.

Although initial studies were performed on the Ramos line, several Ramos sub-lines also exist. Two of these, RA.1 (a direct EBV transformant of the original Ramos), and EHRB (a more lymphoblastoid cell type) were assessed for anti- $\mu$ mAb-induced growth arrest. While RA. 1 cells behaved in a similar manner to the parent line, EHRB cells were found to be particularly sensitive to growth arrest (data not shown) and furthermore succumbed to apoptosis over a period of $24 \mathrm{~h}$ in culture with anti-Fc $\mu \mathrm{mAb}$ (Table 1). EHRB cells were selected for almost all subsequent work. Ramos cells and sublines also have the advantage of being FcR-negative, and so in binding studies whole IgG could be used without interference from $\mathrm{Fc}: \mathrm{FcR}$ interactions.

\section{Growth inhibition with pairs of anti-Fc $\mu$ mAb}

Crossblocking studies showed that the anti-Fc $\mu$ mAb M15/8 and ZL7/5 blocked the binding of each other and so bound to identical or overlapping epitopes on the $\mathrm{Fc}$ region of $\mathrm{IgM}$ (results not shown). The third anti-Fc $\mu \mathrm{mAb}, \mathrm{Mc} 41 / 24 \mathrm{G} 10$, bound to a distinct epitope on the Fc region since its binding was blocked neither by M15/8 nor by ZL7/5. The effect of both non-crossblocking and crossblocking pairs of anti-Fc $\mu$ mAb on DNA synthesis in EHRB and Daudi cells was determined (Figure 2). The results show that on EHRB cells (Figure 2A), the two non-crossblocking pairs of anti-Fc $\mu$ mAb (M15/8+Mc41/24G10, and ZL7/5+Mc41/24G10) were markedly more potent inhibitors than the individual $\mathrm{mAb}$ or the pair of crossblocking antibodies (M15/8+ZL7/5). Interestingly, using Daudi cells (Figure 2B), which are resistant to inhibition by single anti-Fc $\mu \mathrm{mAb}$, pairs of non-crossblocking $\mathrm{mAb}$, like polyclonal anti- $\mu$ (Figure 1B), were quite effective and inhibited growth by more than $70 \%$.

Since $\mathrm{mAb}$ are directed to a single epitope on the $\mathrm{Fc} \mu$ region, the most likely explanation for the enhanced response seen with non-crossblocking pairs, is that they crosslink the surface IgM more extensively. This interpretation would be consistent with the potent inhibition of growth seen with polyclonal anti- $\mu \mathrm{Ab}$ (Figure 1) and suggest that Daudi cells require a higher degree of crosslinking than EHRB in order to generate inhibitory signals.

\section{Growth inhibition with anti-Fc $\mu$ multimers}

As an additional method of investigating the role of crosslinking, the performance of Fab' (univalent), $\mathrm{F}\left(\mathrm{ab}^{\prime}\right)_{2}$ (bivalent) and $\mathrm{F}\left(\mathrm{ab}^{\prime}\right)_{3}$ (trivalent) prepared from the anti-Fc $\mu \mathrm{mAb}$ M15/8 were compared on EHRB cells. The results are shown in Figure 3 and demonstrate that increasing $\mathrm{mAb}$ valency resulted in increased growth inhibition. Thus Fab' fragments were ineffective, $F\left(a b^{\prime}\right)_{2}$ fragments were comparable to the parent $\operatorname{IgG}$, and the $\mathrm{F}\left(\mathrm{ab}^{\prime}\right)_{3}$ species was by far the most effective inhibitor. The insert in Figure 3 shows the level of DNA fragmentation achieved as a result of cells entering apoptosis when cultured with the different anti- $\mu$ mAb fragments. The trivalent $\mathrm{F}\left(\mathrm{ab}^{\prime}\right)_{3}$ induced the highest level of DNA fragmentation. This result was confirmed by measuring the extent of apoptosis in each culture using the method of Nicoletti et al (1991) (Table 1), which showed that the increasing growth inhibition correlated with an increase in the level of apoptosis induced, with the M15/8 Fab', $\mathrm{F}\left(\mathrm{ab}^{\prime}\right)_{2}$ and $\mathrm{F}\left(\mathrm{ab}^{\prime}\right)_{3}$ fragments giving $6 \%, 20 \%$ and $40 \%$ apoptosis. In addition, several other criteria of apoptosis, including annexin $\mathrm{V}$ positivity, chromatin condensation, cell shrinkage and apoptotic body formation, were observed (results not shown). 


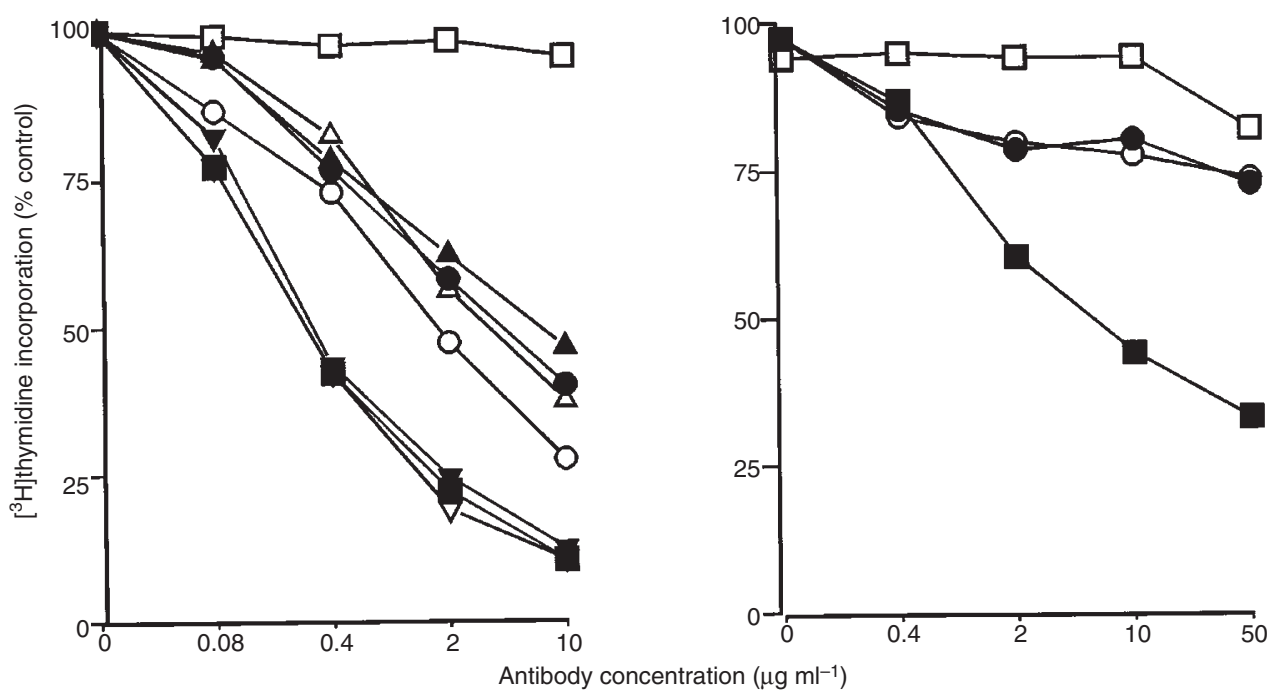

Figure 2 Growth inhibition of EHRB and Daudi cells with pairs of anti-Fc $\mu$ mAbs. EHRB (A) and Daudi (B) cells were incubated with single or pairs of anti-Fc $\mu$ mAb and [3H]thymidine as described in Figure 1. $\square$, irrelevant mAb; $\bullet$, M15/8; O, ZL7/5; $\triangle$, Mc41/24G10; $\mathbf{A}$, M15/8 + ZL7/5; $\mathbf{\square}$, ZL7/5 + Mc41/24G10; $\nabla, \mathrm{M} 15 / 8+\mathrm{Ms} 41 / 24 \mathrm{G} 10 ; \mathbf{\nabla}$, all three anti-Fc $\mu$ mAb. One of at least three similar experiments
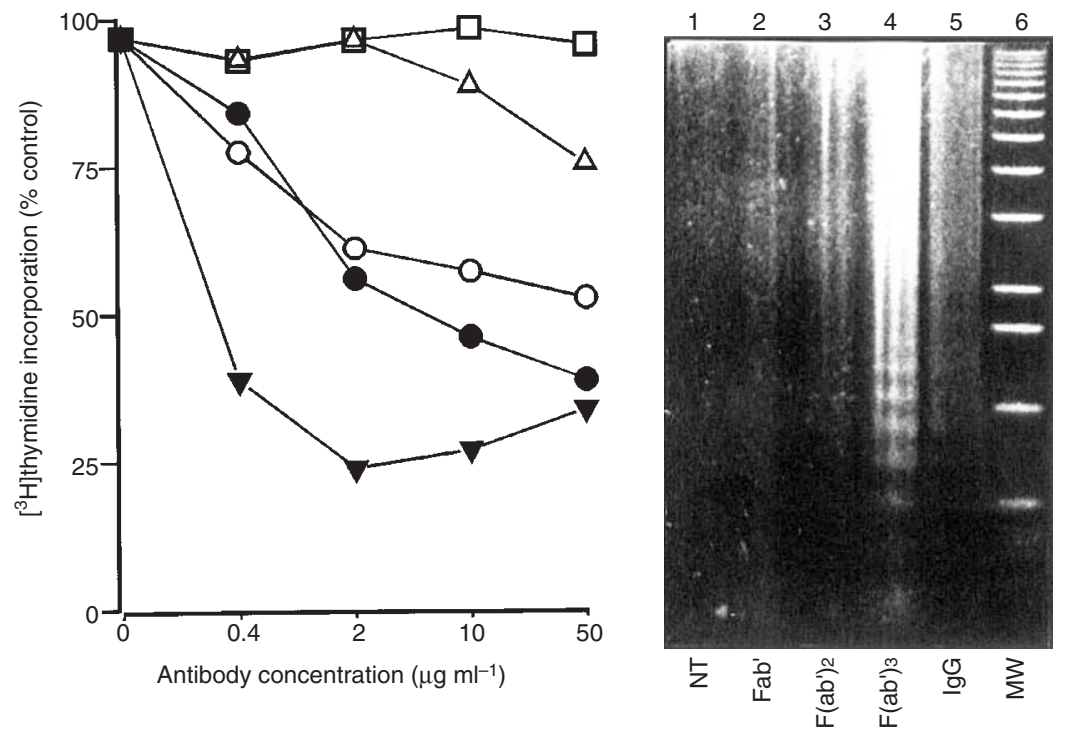

Figure 3 Comparison of growth inhibition of EHRB cells with anti-Fc $\mu a b^{\prime}, F\left(a b^{\prime}\right)_{2}$, and $F\left(a b^{\prime}\right)_{3}$. $F a b^{\prime}, F\left(a b^{\prime}\right)_{2}$, and $F\left(a b^{\prime}\right)_{3}$ fragments were prepared from $\mathrm{M} 15 / 8 \mathrm{IgG}$ as described in Materials and methods. Cells were incubated with antibody and [3H]thymidine as described in Figure 1. $\square$, irrelevant mAb; $\bullet, M 15 / 8$

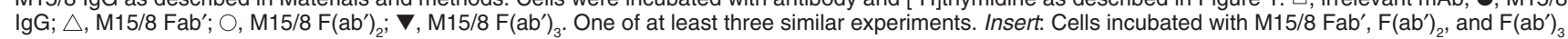
$\left(10 \mu \mathrm{g} \mathrm{ml}^{-1}\right)$ were analysed for DNA fragmentation as described in Materials and methods. Lane 1, untreated; lane 2, Fab'; lane 3, $F\left(a b^{\prime}\right)_{2}$; lane 4, F(ab') lane 5, lgG; lane 6, molecular weight markers

\section{Effect of hyper-crosslinking on growth inhibition}

As an alternative approach to demonstrate the effect of crosslinking IgM on B-cell growth, we used a layer of polyclonal $\mathrm{Ab}$ to extensively crosslink the primary $\mathrm{mAb}$ once it had bound to the cell surface. This is termed hyper-crosslinking. The protocol used in these experiments was to allow primary $\mathrm{mAb}\left(10 \mu \mathrm{g} \mathrm{ml}^{-1}\right)$ to bind to the cell surface for $15 \mathrm{~min}$, and then to remove the cells from excess $\mathrm{mAb}$ by centrifugation before adding the secondary polyclonal anti-mouse $\operatorname{IgG} \mathrm{Ab}$. The effect of hyper-crosslinking anti-Fc $\mu \mathrm{mAb}$ was determined for both EHRB and Daudi cells, and the results are shown in Figure 4. In EHRB cells, hypercrosslinking was extremely effective at inducing growth arrest (Figure 4A), thus while the anti-Fc $\mu \mathrm{mAb}$ alone resulted in a maximum of $20 \%$ inhibition, in the presence of the hypercrosslinking $\mathrm{Ab}$ it was increased to greater than $90 \%$. This enhanced growth inhibition was associated with an increase in the level of apoptosis from $6 \%$ to $43 \%$ (Table 1). With Daudi cells 


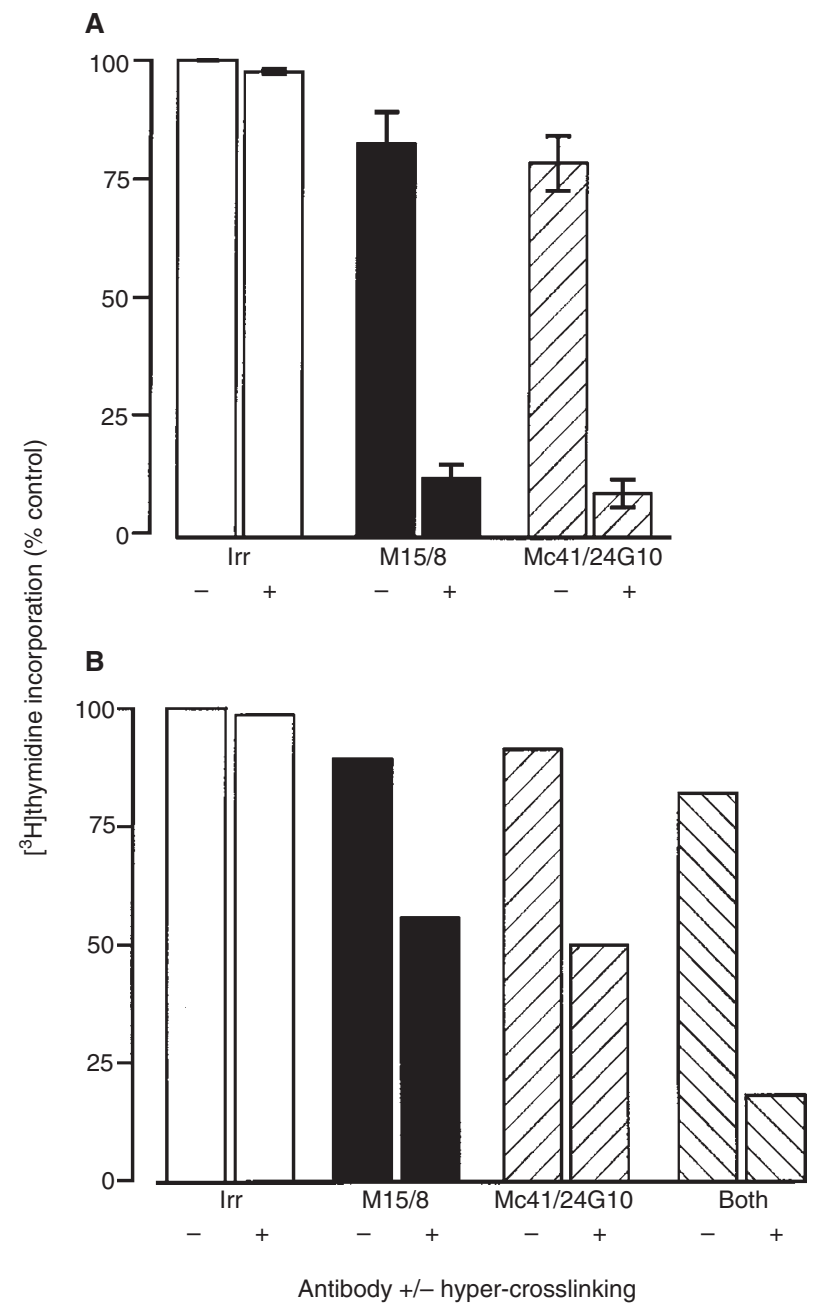

Figure 4 Growth inhibition of EHRB and Daudi cells following hypercrosslinking of anti-Fc $\mu \mathrm{mAb}$. EHRB (A) and Daudi (B) cells were incubated with $\mathrm{M} 15 / 8$ (anti-Fcu) $\mathrm{mAb}$ at $10 \mu \mathrm{g} \mathrm{ml}^{-1}$ for $15 \mathrm{~min}$. They were then harvested by centrifugation, resuspended in medium with or without $20 \mu \mathrm{g} \mathrm{ml}^{-1}$ sheep anti mouse IgG, incubated for $24 \mathrm{~h}$ at $37^{\circ} \mathrm{C}$, and then pulsed overnight with $0.5 \mu \mathrm{Ci} /$ well $\left[{ }^{3} \mathrm{H}\right]$ thymidine. Cells were harvested and the incorporation of radioactivity determined. The results represent mean \pm SD for three experiments for EHRB, and the average of two experiments for Daudi

(Figure 4B) hyper-crosslinking of a single anti-Fc $\mu \mathrm{mAb}$ showed less of an inhibitory effect, giving a maximum of $60 \%$ inhibition. However, when a pair of non-crossblocking anti-Fc $\mu \mathrm{mAb}$ was used (M15/8 + Mc41/24G10), the inhibitory effect of hypercrosslinking was again increased to $90 \%$.

\section{The effect of domain specificity of anti-IgM mAb on growth inhibition}

In the experiments described so far, the mAb used have been directed to epitopes present in the $\mathrm{Fc}$ region of the $\mu$-chain (C $\mu 2-C \mu 4$ domains). We have previously reported (Zhang et al, $1995)$ that compared with these, those mAb recognizing epitopes present in the Fab arms of the IgM molecule (anti-Fd $\mu$, anti-L chain, and anti-Id $\mathrm{mAb}$ ) were comparatively poor in their ability to transduce growth inhibitory signals in Burkitt's cell lines. The results were confirmed and are represented in Figure 5. The two

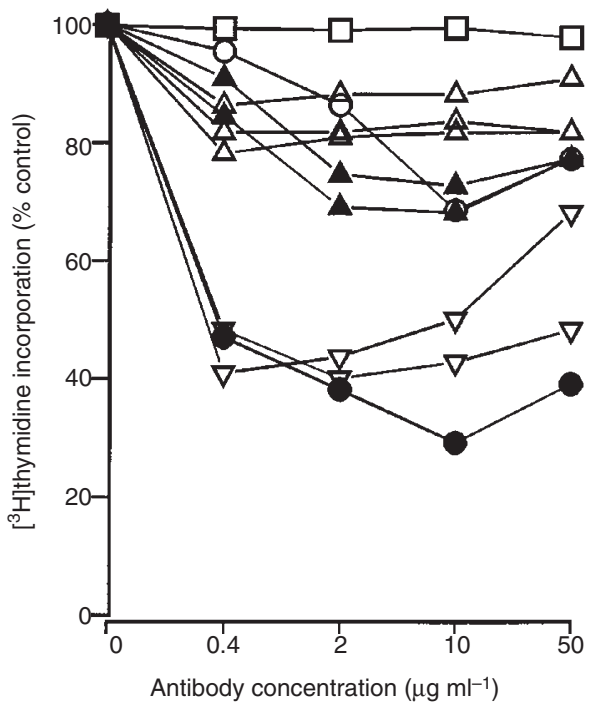

Figure 5 Comparison of growth inhibition of EHRB cells with mAb recognizing different domains of surface IgM. Cells were incubated with $\mathrm{mAb}$ and $\left[{ }^{3} \mathrm{H}\right]$ thymidine as described in Figure 1 . $\square$, irrelevant $\mathrm{mAb} ; \boldsymbol{\bullet}, \mathrm{M} 15 / 8$

(anti-Fcu); $\boldsymbol{\Delta}$, M2E6 and XG9 (anti-Fdu); O, Mc24/1C6 (anti-L chain) (M15/2, another anti-L chain $m A b$ gave a similar result); $\triangle, Z L 16 / 1, Z 116 / 3$, and ZL16/11 (anti-Ramos Id); $\nabla$, pairs of non-crossblocking anti-ld mAb. One of three similar experiments

anti-Fd $\mu$ mAb, XG9 and M-2E6, reduced growth by up to $25 \%$, compared with $65 \%$ for anti-Fc $\mu \mathrm{mAb}$. The anti- $\lambda \mathrm{mAb}$, Mc24/1C6 and M15/2, were also poor at causing growth inhibition as were three mAb specific for the EHRB (Ramos) idiotype, ZL16/1, ZL16/3, and ZL16/11. Crossblocking studies (results not shown) revealed that two of the anti-Id mAb (ZL16/1 and ZL16/3) recognized the same or proximal epitopes on surface $\operatorname{IgM}$, but that the third (ZL16/11) recognized a distinct epitope. In growth arrest assays a mixture of either of the two non-crossblocking pairs, ZL16/1 + ZL16/11 or ZL16/3 + ZL16/11, unlike the single reagents or the crossblocking pair (ZL16/1 + ZL16/3), gave very effective growth inhibition of up to $70 \%$. To determine whether the inhibitory activity of the single anti-Fd $\mu$, anti-L chain or anti-Id $\mathrm{mAb}$ could be increased, the effect of hyper-crosslinking these reagents was investigated. The results in Figure 6 show that all types of anti-IgM mAb were highly effective at inducing growth inhibition when hyper-crosslinked by a second layer of polyclonal $\mathrm{Ab}$.

\section{Stoichiometry and affinity of mAb binding}

We next determined the level of binding of ${ }^{125} \mathrm{I}$-labelled $\mathrm{mAb}$ to EHRB cells; the plots in Figure 7A show the results obtained with representative $\mathrm{mAb}$ of each specificity. IgG from the three anti$\mathrm{Fc} \mu \mathrm{mAb}$ and the two anti-Fd $\mu \mathrm{mAb}$ gave similar saturation curves and levels of binding, with between 15 and $20 \times 10^{4}$ molecules of $\mathrm{mAb}$ binding to each cell. The binding affinities, estimated from these curves, were also similar at around $1 \times 10^{9} \mathrm{M}^{-1}$. Surprisingly, however, IgG from three anti-Id $\mathrm{mAb}$ and the anti- $\lambda$ chain $\mathrm{mAb}$ gave maximum levels of binding of between 35 and $40 \times 10^{4}$ molecules/cell, approximately twice that obtained with the anti-Fc $\mu$ and anti-Fd $\mu \mathrm{mAb}$. Similar binding stoichiometry was obtained with anti-Fc $\mu$ and anti-Id mAb on Daudi cells 


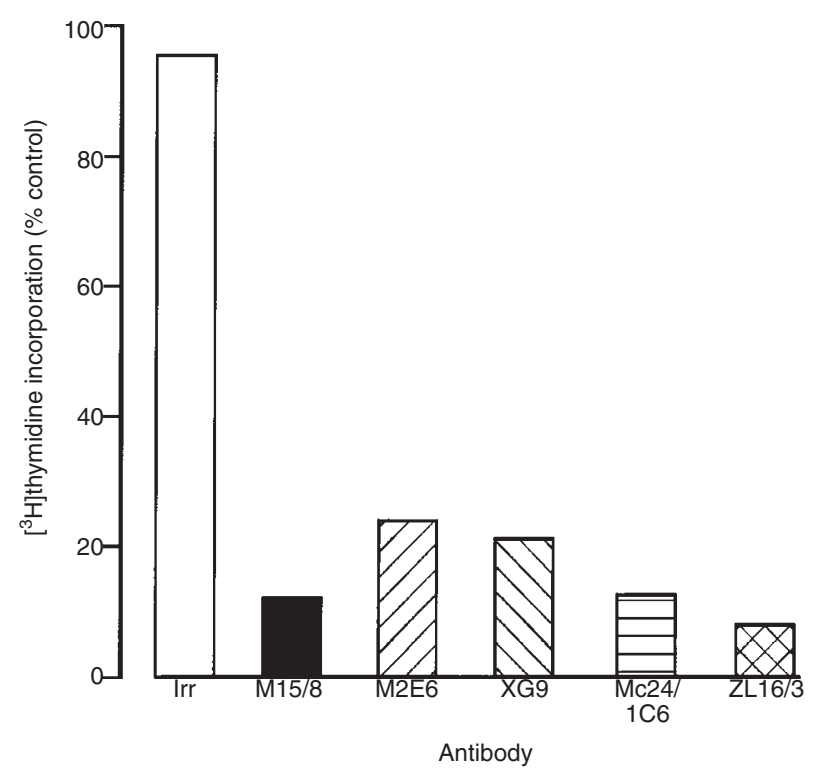

Figure 6 Growth inhibition of EHRB cells following hyper-crosslinking of $\mathrm{mAb}$ recognizing different domains on surface IgM. Cells were incubated with $\mathrm{mAb}$ followed by sheep anti-mouse IgG as described in Figure 4

(anti-Id mAb raised to Daudi IgM) and with anti-Fch and anti-L chain $\mathrm{mAb}$ on Namalwa cells (results not shown): i.e. anti-Id and anti- $\mathrm{L}$ chain $\mathrm{mAb}$ bound approximately twice as many molecules of $\mathrm{mAb}$ per cell as anti-Fc $\mu \mathrm{mAb}$.

In view of these somewhat unexpected findings, we next compared the binding of radiolabelled $\mathrm{F}\left(\mathrm{ab}^{\prime}\right)_{2}$ and $\mathrm{Fab}^{\prime}$ fragments from the anti-Fc $\mu \mathrm{mAb}$ M15/8 (Figure 7B) and the anti-L chain $\mathrm{mAb}$ Mc24/1C6 (Figure 7C). The results are represented as Scatchard plots in Figure 7B and C. The binding pattern obtained with the anti-Fc $\mu \mathrm{mAb}$ preparations (Figure 7B) were as expected, with the $\mathrm{F}\left(\mathrm{ab} \mathrm{b}^{\prime}\right)_{2}$ behaving very like the parent IgG with regard to affinity of binding and the number of molecules bound to each cell, and with the Fab' fragments having a lower affinity and binding approximately twice as many molecules to each cell. These results are consistent with two molecules of univalent Fab' binding to each molecule of surface $\operatorname{IgM}$ and one molecule of bivalent $\mathrm{F}\left(\mathrm{ab} \mathrm{b}^{\prime}\right)_{2}$ binding per surface IgM. In contrast, the affinity and maximum level of binding obtained with $\mathrm{F}\left(\mathrm{ab}^{\prime}\right)_{2}$ and $\mathrm{Fab}^{\prime}$ from the anti-L chain $\mathrm{mAb}$ (Figure 7C) were both surprisingly similar and close to the value obtained with the parent IgG. Thus these results are consistent with the Mc24/1C6 IgG and F( $\left.\mathrm{ab}^{\prime}\right)_{2}$ fragments binding univalently and so giving a 2:1 stoichiometry of $\mathrm{F}\left(\mathrm{ab}^{\prime}\right)_{2}$ :surface IgM.

\section{DISCussION}

In this work we have investigated the ability of various anti-IgM $\mathrm{mAb}$ to induce growth arrest and apoptosis of a number of Burkitt's cell lines. The preliminary screening showed that of eight lines tested, only two, Ramos and Mutu-1, were sensitive to growth inhibition by anti-Fc $\mu \mathrm{mAb}$, and that Daudi cells, although not sensitive to anti-Fc $\mu \mathrm{mAb}$, showed inhibition in response to polyclonal anti-IgM. The differential sensitivity of the lines to anti-IgM inhibition probably relates to a number of factors. George et al (1993) have demonstrated that surface receptor number and density are important criteria in B-cell signalling. Our results showing that anti- $\mu \mathrm{Ab}$, whether polyclonal or monoclonal, was unable to induce growth inhibition in any of the low/medium IgM-expressing cell lines tested (Namalwa, Raji, Bristol-8 and Nalm-6), support this observation. This is in contrast to the reports from Rudich et al (1988) and Mongini et al (1992) who demonstrated that BCRinduced growth inhibition is much less dependent on receptor density than is B-cell activation. The insensitivity of some of the lines may also be related to their differentiation stage, as it is known that BCR ligation only signals for inhibition at certain stages during B-cell development, and may reflect the levels of anti- and proapoptotic proteins present. The EBV status of the cells (Gregory et al, 1991) and whether or not they possess FcR may also influence their sensitivity to growth inhibition and apoptosis. The Ramos EHRB sub-line selected for the main part of the project was exquisitely sensitive to anti-IgM-mAb-induced growth arrest and had the advantage that it did not express FcR, and so the inhibitory response could not be influenced by FcR:Fc interactions.

The two principle findings of the study were: 1) that the more surface IgM was crosslinked by mAb, the more effective was the
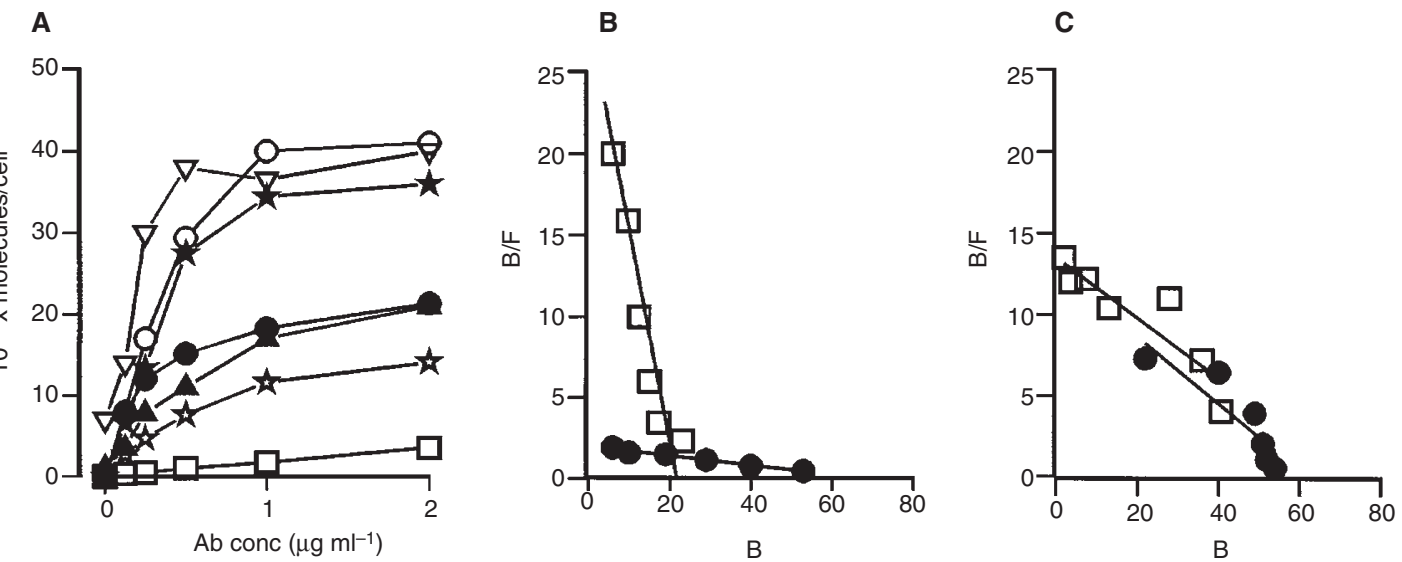

Figure 7 Binding of [ $\left.{ }^{125} \mid\right]$-labelled $\mathrm{mAb}$ to EHRB cells. (A) Serial dilutions of [125]]-labelled $\mathrm{mAb}$ were incubated with EHRB cells $\left(1-2.5 \times 10^{6}\right)$ for $2 \mathrm{~h}$ at $37^{\circ} \mathrm{C}$. The cells were then sedimented through phthalate oils and the pellet counted for radioactivity. The results are expressed as the number of antibody molecules

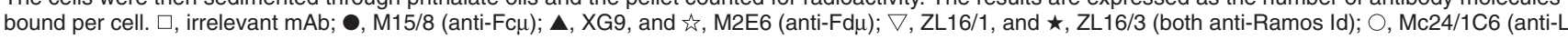
chain). One of at least three similar experiments. (B, C) Scatchard plots to compare the binding of $F\left(a b^{\prime}\right)_{2}(\square)$ and Fab' $(\mathbf{})$ from M15/8 (B) and Mc24/1C6 (C) to EHRB cells. B, molecules bound per cell $\left(\times 10^{-4}\right)$; F, free antibody concentration $(\mathrm{M})$ 
resultant growth arrest and apoptosis; and 2) that the ability of a single $\mathrm{mAb}$ to induce crosslinking was highly dependent on epitope specificity. A range of experiments using anti-IgM mAb (single or cocktails), polyclonal anti- $\mu \mathrm{Ab}$, and hyper-crosslinking, all showed that growth arrest of B-cell lines was highly dependent on the extent of IgM crosslinking. These observations were confirmed by varying the valency of the mAb by using Fab', $\mathrm{F}\left(\mathrm{ab}^{\prime}\right)_{2}$ and $\mathrm{F}\left(\mathrm{ab} \mathrm{b}^{\prime}\right)_{3}$ derivatives from anti-Fc $\mu \mathrm{mAb}$. Here the progressive increase in valency resulted in a corresponding decrease in cell proliferation, presumably as a result of more efficient BCR-crosslinking on the cell surface. Furthermore, we were able to show that cells treated with a trivalent $F\left(a b^{\prime}\right)_{3}$ anti- $\mu$ derivative underwent extensive DNA fragmentation indicating induction of apoptosis (insert to Figure 3).

Interestingly, the ability of single $\mathrm{mAb}$ to mediate $\operatorname{IgM}$ crosslinking activity was dependent on their epitope specificity. Thus, mAb directed at the $\mathrm{Fc}$ region $(\mathrm{C} \mu 2-\mathrm{C} \mu 4$ domains) of surface IgM were much more effective at crosslinking B-cell IgM and inducing growth arrest, than were those directed at Fab region (anti-L chain, anti-Id and anti-Fd $\mu$ ) of this molecule. Only when these latter $\mathrm{mAb}$ were hyper-crosslinked with polyclonal antimouse IgG did they cause appreciable growth arrest and apoptosis. Binding studies showed that this difference in function was not related to any marked disparity in the affinity of the $\mathrm{mAb}$ studied which were all in the range $1-4 \times 10^{9} \mathrm{M}^{-1}$ (Figure 6). In view of the results showing the importance of crosslinking in achieving growth inhibition, this probably relates to the intrinsic crosslinking capacity of the mAb, and depends on whether the anti-Fc and antiFab mAb bind to surface IgM bigamously or monogamously (Elliot et al, 1987). mAb that bind bigamously, with epitopes or adjacent BCR complexes, form effective inter-BCR crosslinks, and those that bind monogamously, with the epitopes on a single surface IgM molecule, have poor crosslinking capacity. Rudich et al (1988) have provided evidence using immunoelectron microscopy that whereas the anti-Fd $\mu \mathrm{mAb}$ XG9, used in this study, binds in a predominantly monogamous manner, an anti-Fc $\mu \mathrm{mAb}, 1 \mathrm{G} 6$, binds predominantly bigamously. This could explain the inefficacy of XG9 in our assays and supports the hypothesis that bigamous binding is a requirement for BCR-induced growth inhibition. Grafton et al (1997) have recently published a study using a large panel of anti-IgM mAb recognizing the $\mathrm{C} \mu 2-\mathrm{C} \mu 4$ domains of the Fc region. They show that most of these $\mathrm{mAb}$ were able to induce growth inhibition; interestingly, although the panel did not include any mAb recognizing the anti-Fd $\mu$ region (C $\mu \mathrm{l}$ domain), two anti-Id $\mathrm{mAb}$ in the panel failed to cause growth inhibition.

Although initially the lack of efficacy of the anti-L chain and anti-Id $\mathrm{mAb}$ was also attributed to a predominantly monogamous type binding, the results of the ${ }^{125}$ I-labelled mAb binding experiments suggested an alternative explanation (Figure 7). The maximum level of binding to EHRB cells obtained with IgG from the anti-L chain and anti-Id mAb was twice that obtained with the anti-Fc $\mu$ and anti-Fd $\mu$ mAb. Similar results were obtained with anti-Id mAb on Daudi cells and anti-L chain mAb on Namalwa cells. Assuming that the stoichiometry of anti-Fd $\mu$ and anti-Fc $\mu$ $\mathrm{mAb}$ binding to surface IgM molecule is $1: 1$, this suggests that two molecules of anti-L chain or anti-Id $\mathrm{mAb}$ were bound per surface IgM, and therefore favours the idea that their binding was predominantly univalent rather than bivalent, and that this is the reason for their poor growth inhibitory capacity. The comparison of the binding of $\mathrm{F}\left(\mathrm{ab}^{\prime}\right)_{2}$ and $\mathrm{Fab}^{\prime}$ fragments (Figure 7) was consistent with this interpretation, since, in contrast to the results obtained with fragments from the anti-Fc $\mu$ mAb M15/8, $\mathrm{Fab}^{\prime}$ and $\mathrm{F}\left(\mathrm{ab}^{\prime}\right)_{2}$ from anti- $\mathrm{L}$ chain $\mathrm{mAb}$ gave a similar value for maximum binding and binding affinity.

In view of the therapeutic success of anti-Id mAb in certain Bcell malignancies (Vuist et al, 1994; Racila et al, 1995; Tutt et al, 1998), the inability of any of the three anti-Ramos Id mAb (and two for Daudi) to cause growth inhibition in vitro was somewhat surprising. This is particularly important because there is growing support for the idea that a number of therapeutic anti-lymphoma $\mathrm{mAb}$, including anti-Id and anti-CD20, may be operating via a direct signalling route, rather than by the recruitment of cytotoxic effector cells (Tutt et al, 1998). However, our results showed that irrespective of the ability of an individual $\mathrm{mAb}$ to induce growth inhibition, after hyper-crosslinking all $\mathrm{mAb}$ were equally potent. The ability of anti-Id $\mathrm{mAb}$ to induce transmembrane signalling and growth arrest in vivo is probably dependent on a number of factors other than their intrinsic crosslinking activity, which we have measured. For example, we can expect that FcR-bearing effector cells might play an important role in delivering hyper-crosslinking to anti-Id mAb-coated target cells. In this situation many FcRcarrying cells such as NK-cells, monocytes, neutrophils, endothelial cells or perhaps even B-cells would be effective at delivering cytotoxic signal. Thus effector cells would not necessarily need to be cytotoxic in themselves, but would simply need to deliver a multivalent array of FcR to hyper-crosslink the BCR. In support of this suggestion, recent work from Shan et al (1998) shows that the ability of another apoptosis-inducing mAb, anti-CD20, is markedly enhanced by the addition of FcR-bearing effector cells to the cultures. The presence of FcR-bearing cells has also been shown to enable a $\mathrm{mAb}$ recognizing $\mathrm{CD} 79 \beta$, a signalling component of the BCR, to induce inhibitory signals (Van Kooten et al, 1997). The results presented here show that in vitro most anti-Id $\mathrm{mAb}$ are particularly ineffective at crosslinking the BCR to mediate growth arrest, suggesting that their success in vivo probably require an additional form of crosslinking.

\section{ACKNOWLEDGEMENTS}

We would like to thank Dr A Milner and Prof Chris Gregory (Birmingham) and Dr Bill Cushley (Glasgow) for cell lines, and Dr P Mongini (New York) for antibody. This work was supported by Tenovus of Cardiff, the European Union, and the Leukaemia Research Fund.

\section{REFERENCES}

Bonardi MA, French RR, Amlot P, Gromo G, Modena D and Glennie MJ (1993) Delivery of saporin to human B-cell lymphoma using bispecific antibody targeting via CD22 but not CD19, CD37 or immunoglobulin results in efficient killing. Cancer Res 53: 3015-3021

De Franco AL, Raveche ES, Asofsky R and Paul WE (1982) Frequency of lymphocytes b responsive to anti-immunoglobulin. J Exp Med 155: 1523-1536

Elliot TJ, Glennie MJ, McBride HM and Stevenson GT (1987) Analysis of the interaction of antibodies with immunoglobulin idiotype of neoplastic B lymphocytes; implications for immunotherapy. J Immunol 138: 981-988

George J, Penner SJ, Weber J, Berry J, Caflin JL (1993) Influence of membrane Ig receptor density and affinity on B cell signaling by antigen. J Immunol 151: 5955-5965

Glennie MJ, Tutt AL and Greenman J (1993) Preparation of multispecific F (ab') and $\mathrm{F}\left(\mathrm{ab}^{\prime}\right)_{3}$ antibody derivatives. In Tumour Immunobiology, a Practical Approach, Rees RC, Reynolds CW (eds), pp. 225-244. Oxford University Press: Oxford 
Gold MR, Matsuuchi L, Kelly RB and De Franco AL (1991) Tyrosine phosphorylation of components of the B-cell antigen receptors following receptor crosslinking. Proc Natl Acad Sci USA 88: 3436-3440

Grafton G, Goodall M, Gregory CD and Gordon J (1997) Mechanisms of antigen receptor-dependent apoptosis of human B lymphoma cells probed with a panel of 27 monclonal antibodies. Cell Immunol 182: 45-56

Gregory CD, Dive C, Henderson S, Smith CA and Williams GT (1991) Activation of EBV latent genes protects human B cells from death by apoptosis. Nature 349: $612-614$

Gregory CD, Rowe M and Rickinson AB (1990) Different EBV-B cell interactions in phenotypically distinct clones of a Burkitt's lymphoma cell line. J Gen Virol 71: $1481-1495$

Hasbold J and Klaus GGB (1990) Anti-immunoglobulin antibodies induce apoptosis in immature B-cell lymphomas. Eur J Immunol 20: 1685-1690

Marches R, Racila E, Tucker TF, Picker L, Mongini P, Hsueh R, Vitetta ES, Scheuermann RH and Uhr JW (1995) Tumour dormancy and cell signalling III: role of hypercrosslinking of IgM and CD40 on the induction of cell cycle arrest and apoptosis in B lymphoma cells. Therap Immunol 2: 125-136

Nicoletti I, Migliorati G, Pagliacci MC, Grignani F and Riccardi C (1991) A rapid and simple method for measuring thymocyte apoptosis by propridium iodide staining and flow cytometry. J Immunol Methods 139: 271-279

Racila E, Schuermann RH, Picker LJ, Yefenof E, Tucker T, Chang W, Marches R, Street NE, Vitetta ES and Uhr JW (1995) Tumor dormancy and signalling, II. Antibody as an agonist in inducing dormancy of a B cell lymphoma in SCID mice. J Exp Med 181: 1539-1550
Rudich SM, Roux KH, Winchester RJ and Mongini PKA (1988) Anti-IgM B cell mediated signaling - molecular analysis of ligand binding requisites for human B cell clonal expansion and tolerance. J Exp Med 168: 247-266

Sefton BM and Campbell MA (1991) The role of tyrosine phosphorylation in lymphocyte activation. Ann Rev Cell Biol 7: 257-274

Shan, D, Ledbetter JA and Press OW (1998) Apoptosis of malignant human B cells by ligation of CD20 with monoclonal antibodies. Blood 91: 1644-1652

Tutt AL, Stevenson GT and Glennie MJ (1991) Trispecific F(ab) derivatives that use cooperative signalling via the TCR/CD3 complex and CD2 to activate and redirect resting cytotoxic T cells. J Immunol 147: 60-69

Tutt AL, French RR, Illidge TM, Honeychurch J, McBride H, Penfold C, Fearon DT, Parkhouse ME, Klaus GGB and Glennie MJ (1998) Monoclonal antibody therapy of B-cell lymphoma: signaling activity on tumour cells appears more important than recruitment of effectors. J Immunol (in press)

Van Kooten, Galiber L, Seon BK, Garrone P, Liu Y-J and Banchereau J (1997) Cross-linking of antigen receptor via Ig- $\beta$ (B29, CD79b) can induce both positive and negative signals in CD40 activated human B cells. Clin Exp Immunol 110: 509-515

Vuist WMJ, Levy R and Maloney DG (1994) Lymphoma regression induced by monoclonal anti-idiotype antibodies correlates with their ability to induce Ig signal transduction and is not prevented by tumour expression of high levels of bcl-2 protein. Blood 83: 899-906

Zhang I, French RR, Chan HTC, Cragg MS, Power MJD and Glennie MJ (1995) The development of anti-CD79 monoclonal antibodies for treatment of B-cell neoplastic disease. Therap Immunol 2: 191-202 